\title{
RENDAHNYA MINAT PENDIDIKAN PADA MASYARAKAT PETANI SINGKONG KELURAHAN SAPAYA KECAMATAN BUNGAYA KABUPATEN GOWA
}

\author{
Muslimin', Muhammad Syukur $^{2}$ \\ 1,2Program Studi Pendidikan Sosiologi, Fakultas Ilmu Sosial, Universitas Negeri Makassar \\ miminmuslimin@gmail.com ${ }^{1}$, m.syukur@unm.ac.id ${ }^{2}$
}

\begin{abstract}
ABSTRAK
Penelitian ini bertujuan untuk mengetahui; 1) Faktor apa yang menyebabkan rendahnya minat pendidikan pada masyarakat petani singkong Kelurahan Sapaya, Kecamatan Bungaya Kabupaten Gowa. 2) Upaya apa yang bisa dilakukan untuk meningkatkan pendidikan pada masyarakat petani singkong kelurahan sapaya, kecamatan bungaya kabupaten gowa. Jenis penelitian ini adalah kualitatif deskriptif. Teknik dalam menentukan informan menggunakan purposive sampling, dengan kriteria yaitu masyarakat petani singkong, berjenis kelamin laki-laki, dan berumur 20-42 tahun yang ada di Kelurahan Sapaya Kecamatan Bungaya Kabupaten Gowa. Teknik pengumpulan data yang digunakan yaitu observasi, wawancara, dan dokumentasi. Teknik analisis data kualitatif tipe deskriptif melalui tiga tahap yaitu reduksi data, penyajian data dan penarikan kesimpulan. Teknik pengabsahan data menggunakan membercheck. Hasil penelitian menunjukkan bahwa; 1) Faktor yang menyebabkan rendahnya minat pendidikan pada masyarakat petani singkong sehingga pada umumnya putus sekolah dan tidak lanjutnya ke jenjang pendidikan selanjutnya di masyarakat petani singkong di Kelurahan Sapaya Kecamatan Bungaya Kabupaten Gowa yaitu disebabkan oleh yaitu faktor membantu orang tua, faktor ekonomi, faktor pergaulan dan faktor kurangnya minat belajar. 2) Upaya yang dilakukan dalam meningkatkan pendidikan yaitu pendidikan formal dan pendidikan nonformal di masyarakat petani singkong di Kelurahan Sapaya Kecamatan Bungaya Kabupaten Gowa.
\end{abstract}

Kata kunci: Minat Pendidikan, Petani Singkong

\section{ABSTRACT}

This study aims to determine; 1) What factors cause the low interest in education in the cassava farming community of Sapaya Village, Bungaya District, Gowa Regency. 2) What efforts can be done to improve education in the cassava farmers community, Sapaya village, Bungaya sub-district, Gowa district. This type of research is descriptive qualitative. The technique in determining informants uses purposive sampling, with the criteria being cassava farming community, male sex, and aged 20-42 years in Sapaya Village, Bungaya District, Gowa Regency. Data collection techniques used are observation, interviews, and documentation. Descriptive type qualitative data analysis techniques through three stages, namely data reduction, data presentation and conclusion drawing. The data validation technique is using member check. The results showed that; 1) Factors causing low interest in education in cassava farming communities so that generally dropping out of school and not continuing to the next level of education in cassava farming communities in Sapaya Village Bungaya District Gowa Regency is caused by factors that help parents, economic factors, social factors and the lack of interest in learning. 2) Efforts to improve education are formal and non-formal education in the cassava farming community in Sapaya Village, Bungaya District, Gowa Regency.

Keywords: Interest in Education, Cassava Farmers

\section{PENDAHULUAN}

Manusia adalah mahkluk yang memiliki kemampuan yang lebih unggul di banding mahkluk lain. Setiap manusia lahir dalam keadaan membawa potensi masing-masing, hanya harus di kembangkan dengan cara mengasah potensi yang telah ada. Mengasah potensi yang ada dengan belajar mengembangkan potensi tersebut agar mampu menjadi sebuah kemampuan. Pendidikan adalah salah satu cara untuk mengembangkan potensipotensi yang ada pada diri manusia agar dapat berkembang. Pendidikan adalah proses dari 
tidak tahu menjadi tahu. Pendidikan adalah sarana yang penting bagi manusia dalam mengasah potensi yang ada pada dirinya. Pendidikan adalah segala pengalaman belajar yang berlangsung dalam segala lingkungan dan sepanjang hidup. (Seknun, 2014)

Pendidikan berlangsung dalam segala lingkungan baik yang khusus diciptakan untuk kepentingan pendidikan maupun yang ada dengan sendirinya. Pendidikan berlangsung seumur hidup di setiap saat selama ada pengaruh lingkungan. Pendidkan dapat berbentuk formal, informal, dan nonformal. Kegiatan pendidikan bisa berupa bimbingan, pengajaran, atau latihan. Pendidikan merupakan usaha yang direncanakan (DKB, 2007).

Pendidikan yang ada dalam kalangan masyarakat awam memiliki pelekatan yang tidak terlalu kuat, itu terlihat di berbagai wilayah yang ada di Indonesia, masih banyak yang menganggap pendidikan sesuatu hal yang biasa saja dan tidak terlalu menarik untuk melaksanakan pendidikan. Kalangan masyarakat yang masih tertinggal dalam pendidikan adalah lebih banyak dari masyarakat petani. Dalam status Negara agraris, dimana sebagian besar masyaratkatnya hidup dari bercocok tanam dan sektor pertanian Indonesia masih dalam perkembangan pendidikan, terutama dalam kalangan petani (Tarpuhawa, 2018).

Usia petani-petani yang di Indonesia itu juga semakin tua karena kebanyakan anakanaknya tidak mau meneruskan orang tuanya menjadi petani. Selain usia yang semakin menua, masalah petani yang ada di Indonesia juga tingkat pendidikannya yang rendah, hal ini yang dilihat oleh penulis terutama yang ada Kabupaten Gowa atau lebih tepatanya yang ada di Kelurahan Sapaya Kecamatan Bungaya Kabupaten Gowa. Kelurahan sapaya adalah wilayah yang penduduknya atau masyarakatnya banyak yang merupakan seoarang petani. Salah satu petani yang banyak di Kelurahan Sapaya adalah petani singkong. Singkong adalah makanan yang banyak dibutuhkan oleh masyarakat pada umumnya di tempattempat tertentu sehingga ada banyak masyarakat yang ada di Kelurahan Sapaya yang menjadikan petani singkong sebagia pendapatan utamanya.

Tetapi dengan pendapatan yang ada pada profesi sebagai petani singkong yang ada di Kelurahan Sapaya membuat petani singkong fokus pada profesi tersebut, sehingga masyarakat yang mempunyai pendidikan jarang ditemui pada masyarakat petani singkong. Hal ini disebabkan karena petani singkong lebih berminat pada pertanian yang telah turun temurun di kerjakan oleh masyarakat yang di Kelurahan Sapaya. Minat terhadap pendidikan masih sangat kurang sehingga banyak yang di temui masyarakat atau pemuda yang tidak lanjut sekolah atau tidak memiliki pendidikan formal sama sekali.

Petani singkong yang ada di Kelurahan Sapaya yang pendidikannya perlu di perhatikan kerena menjadi sebuah hal yang sangat penting. Pendidikan tidak di anggap sebagai solusi oleh kebanyakan masyarakat yang ada di Kelurahan Sapaya, banyak orang tua yang tidak mengdukung anak-anaknya untuk bersekolah atau menlanjutkan sekolah ke yang lebih lanjut. Salah satu dusun yang ada di Kelurahan Sapaya yaitu, Lingkungan Kareta dimana fokus penulis, Lingkungan Kareta banyak memiliki masyarakat petani terutama masyarakat petani singkong dibanding dusun-dusun lainnya yang ada di Kelurahan Sapaya, berdasarkan observasi yang dilakukan, Lingkungan Kareta menjadi fokus penulis, Lingkungan Kareta menjadi dusun yang memiliki banyak masyarakat yang tidak memiliki pendidikan formal dan menjadi penyetor anak mudah yang tidak sekolah atau tidak lanjut bersekolah.

Hasil observasi awal ditemukan bahwa tingkat pendidikan masyarakat penati singkong dikeluarahan Sapaya adalah tidak ditemukan adanya sarjana di desa tersebut. Tingkat Sekolah Menengah Atas 17 orang, Sekolah Menengah Pertama 57 orang, Sekolah Dasar 117 orang, Putus Sekolah 263, Tidak pernah sekolah 116 orang. Data ini diperolah dari kantor kelurahan sapaya. Dari data ini memperlihatkan minimnya minat pendidikan 


\section{Jurnal Sosialisasi \\ Jurnal Hasil Pemikiran, Penelitian, dan Pengembangan \\ Keilmuan Sosiologi Pendidikan \\ Vol 7, Nomor 1, Maret 2020}

pada kalangan petani singkong. Dari 550 orang petani ada $44.18 \%$ yang putus sekolah, ini memperlihatkan bahwa masih banyak sekali masyarakat petani yang memiliki pendidikan yang rendah atau sama sekali tidak memiliki pendidikan formal. Penelitian ini bertujuan untuk mengetahui faktor apa yang menyebabkan rendahnya minat pendidikan pada masyarakat petani singkong Kelurahan Sapaya, Kecamatan Bungaya Kabupaten Gowa. Serta upaya apa yang bisa dilakukan untuk meningkatkan pendidikan pada masyarakat petani singkong kelurahan sapaya, kecamatan bungaya kabupaten gowa.

\section{METODE PENELITIAN}

Metode penelitian yang digunakan dalam penelitian ini adalah metode penelitian kualitatif. Penelitian kualitatif merupakan metode penelitian yang berlandaskan pada filsafat postpositivisme, digunakan untuk meneliti pada kondisi obyek yang alamiah, (sebagai lawannya adalah eksperimen) dimana peneliti adalah sebagai instrument kunci, pengambilan sampel sumber data dilakukan secara purposive dan snowball, teknik pengumpulan dengan trianggulasi (gabungan), analisis data bersifat induktif/kualitatif, dan hasil penelitian kualitatif lebih menekankan makna dari pada generalisasi (Upe, 2016).

Penelitan kualitatif dari sisi definisi lainnya di kemukakan bahwa hal itu merupakan penelitian yang memanfaatkan teknik pengumpulan data yang bersifat tragulasi, yaitu menggunakan beberapa teknik penngumpulan data secara gabungan/simultan. Analisis data yang dilakukan bersifat induktif berdasarkan fakta-fakta yang ditemukan di lapangan dan kemudian dikonstruksikan menjadi hipotesis atau teori. Metode penelitian kualitatif digunakan untuk mendapatkan data yang mendalam, suatu data yang mengandung makna. Teknik dalam menentukan informan menggunakan purposive sampling, dengan kriteria yaitu masyarakat petani singkong, berjenis kelamin laki-laki, dan berumur 20-42 tahun yang ada di Kelurahan Sapaya Kecamatan Bungaya Kabupaten Gowa. Teknik pengumpulan data yang digunakan yaitu observasi, wawancara, dan dokumentasi. Teknik analisis data kualitatif tipe deskriptif melalui tiga tahap yaitu reduksi data, penyajian data dan penarikan kesimpulan (Miles \& Huberman, 1994). Teknik pengabsahan data menggunakan membercheck

\section{HASIL PENELITIAN DAN PEMBAHASAN}

Untuk memperjelas hasil penelitian yang telah dipaparkan di atas, maka penulis akan membahas mengenai data-data yang diperoleh dari lokasi penelitian. Untuk lebih jelasnya dipaparkan sebagai berikut:

\section{Faktor Yang Mempengaruhi Rendahnya Minat Pendidikan Pada Masyarakat Petani} Singkong Di Kelurahan Sapaya Kecamatan Bungaya Kabupaten Gowa.

Pada pembahasan ini akan di bahas tentang faktor yang menyebabkan masyarakat petani singkong di Kelurahan Sapaya putus sekolah dan tidak melanjutkan pendidikan ke jenjang selanjutnya. Faktor penyebab terjadinya putus sekolah dan tidak dilanjutkannya pendidikan kejenjang selanjutnya ada lima yaitu faktor kesadaran pribadi, faktor ekonomi, faktor pergaulan, faktor kurangnya pemahaman tentang pentingnya pendidikan, dan kurangnya minat belajar. Berdasarkan penelitian yang telah dilakukan, ditemukan bahwa lima faktor tersebutlah yang menjadi pendorong atau penyebab putus sekolah dan tidak melanjutkan ke jenjang selajutnya.

Pertama, faktor membantu orang tua, Jadi dari hasil obsevasi dan penelitian yang dilakukan oleh peneliti menunjukkan sebagian besar masyarakat yang putus sekolah atau benar-benar tidak pernah mengecam pendidikan formal disebabkan dari dalam individu masyarakat tersebut, utamanya dari kesadaran diri sendiri sehingga tidak berminat untuk 
bersekolah. Ini terjadi karena dorongan dari dalam diri individu tersebut untuk berpendidikan atau bersekolah sangat kurang bahkan mungkin tidak ada. Tidak adanya kesadaran untuk melanjutkan pendidikan atau berhenti sekolah disebabkan oleh kurangnya kesadaran masyarakat Keluarah Sapaya terhadap pendidikan dikarenakan lamanya waktu yang dibutuhkan untuk menuntaskan pendidikan, dalam arti meneyelesaikan pendidikan formal hingga mendapatkan gelar sarjana, yaitu kurang lebih 16 tahun. Padahal belum tentu setelah mendapatkan gelar sarjana maka akan langsung mendapatkan pekerjaan seperti yang kita inginkan, faktanya sekarang ini banyak sarjana yang menganggur akibat kurangnya lapangan pekerjaan dan cepatnya pertubuhan masyarakat.

Kedua, faktor ekonomi, dari hasil obsevasi dan penelitian menunjukkan ada sebagian besar masyarakat petani singkong Kelurahan Sapaya yang memilih tidak melanjutkan pendidikan dan putus sekolah di Kelurahan Sapaya, dikarenakan lebih memilih bekerja daripada bersekolah karena di sebabkan oleh faktor ekonomi. Karena mereka berpikiran, bahwa bekerja dapat membatu perekonomian keluarganya. Faktor ekonomi orang tua masih menjadi penyebab masyarakat dan anak putus sekolah di Kelurahan Sapaya, ini terjdi juga di kalangan masyarakat petani singkong yang ada di Keluarahan Sapaya. Banyak masyarakat atau anak-anak putus sekolah karena bekerja membatu orang tua dalam memenuhi perekonomian keluarga. Bertani adalah pekerjaan yang paling banyak di lakukan oleh anak-anak yang putus sekolah atau masyarakat yang tidak melanjutkan pendidikannya ke jenjang selanjutnya. Namun demikian, akibat tekanan kemiskinan, kurangnya anomi orang tua terhadap arti pentingnya pendidikan, dan sejumlah faktor lain, maka secara sukarela maupun terpaksa anak menjadi salah satu sumber pendapatan keluarga yang penting. Yang didapatkan oleh penulis pada penelitian di Kelurahan Sapaya Kecamatan Bungaya Kabupaten Gowa ialah bahwa faktor ekonomi menjadi faktor yang berpengaruh dalam banyaknya masyarakat dan anak-anak yang putus sekolah dan tidak melanjutkan pendidikannya ke jenjang selanjutnya.

Ketiga, faktor pergaulan, dari hasil obsevasi dan penelitian menunjukkan masyarakat petani yang ada di Kelurahan Sapaya sebagian besar lebih memilih tidak melanjutkan pendidikan dan putus sekolah di Kelurahan Sapaya tersebut karena adanya pengaruh dari masyarakat lain ataupun lingkungan sosial seperti teman bergaul dimana seseorang itu tinggal, karena suatu perkembangan jiwa seorang anak banyak di pengaruhi oleh pergaulan. Faktor pergaulan ini sangat berpengaruh pada kelangsungan pendidikan pada masyarakat petani singkong yang ada di Kelurahan Sapaya. Faktor pergaulan sosial di kalangan anak muda juga menjadi penyebab berkurangnya jumlah anak yang bersekolah di Kelurahan Sapaya Kecamatan Bungaya Kabupaten Gowa.

Mereka terbawa oleh arus pergaulan di kalangan anak-anak yang lebih menyukai kesenangan sesaat, dan menganggap sekolah merupakan kekangan bagi mereka. Dan ketika mereka mulai besar anak-anak mulai bisa bekerja membatu orang tua dan memdapatkan uang sendiri dan bisa memenuhi kebutuhannya dan sekolah pun terlupakan bagi mereka. Hiburan yang sering di adakan di kampung-kampung memberi ruang kepada anak-anak untuk mengalami kehidupan "yang menyenangkan" seperti band, saweran, dan lainnya.

Keempat, faktor kurangnya minat belajar, dari penelitian yang dilakukan oleh peneliti telah menemukan pendapat sebagian besar masyarakat petani singkong yang di Kelurahan Sapaya. Kurangnya minat belajar termasuk kemalasan masyarakat atau anakanak yang ada di keluarahan sapaya. Penyebab anak putus sekolah bukan hanya masalah ekonomi tapi berasa dari kurangnya minat belajar dan kurang minat untuk pergi sekolah. Alasan kurang minat belajar juga di karenakan kurang menariknya cara belajar yang 
mereka harus hadapi setiap hari di sekolah dan juga belum menyadari pentingnya belajar untuk masa depan mereka, sehingga kurang termotivasi untuk berprestasi.

\section{Upaya apa yang bisa dilakukan untuk meningkatkan pendidikan pada masyarakat} petani singkong Kelurahan Sapaya, Kecamatan Bungaya Kabupaten Gowa

Upaya yang bisa dilakukan untuk meningkatkan pendidikan pendidikan pada masyarakat petani singkong Kelurahan Sapaya, Kecamatan Bungaya Kabupaten Gowa. Upaya ini terbagi dalam dua bagian yaitu upaya pendidikan formal dan upaya pendidikan nonformal. Berdasarkan penelitian yang di lakukan penulis bahwa kedua upaya tersebut menjadi cara meningkatnya pendidikan di masyarakat petani singkong yag ada di Kelurahan Sapaya.

Pertama, pendidikan formal, dari penelitian yang dilakukan peneliti telah menemukan sebagian besar pendapat dari informan tentang upaya yang dilakukan masyarakat petani singkong yang ada di Kelurahan Sapaya. Upaya yang di lakukan ialah memberikan dukungan terhadap anak-anak mereka untuk mengenyam pendidikan formal sehingga putus sekolah atau tidak melanjutkan tidak terjadi lagi di keluarga masing-masing informan atau masyarakat petani singkong yang ada di Kelurahan Sapaya.

Pendidikan formal adalah jalur pendidikan dasar dan berjenjang yang terdiri atas pendidikan anak usia dini (TK/RA), pendidikan dasar (SD/MI), pendidikan menengah (SMP/MTs), dan (SMA/MA), dan pendidikan tinggi (Universitas) (Indonesia, 2005). Pendidikan formal terdiri dari pendidikan formal berstatus negeri dan pendidikan formal berstatus swasta (Hidayat, Anwar, \& Hidayah, 2017). Berdasarkan penelitian yang di lakukan, ditemukan bahwa pendidikan formal memjadi upaya sebagian besar masyarakat petani singkong di Kelurahan Sapaya dalam meningkatkan pendidikan.

Kedua, upaya pendidikan nonformal, dari hasil observasi dan penelitian yang di lakukan ditemukan sebagian besar pendapat dari informan yang ada di Kelurahan Sapaya sebuah pendidikan nonformal sebagai upaya dalam melanjutkan pendidikan yang tidak berlanjut pada pendidikan formal. Ada beberapa pendidikan nonformal yang diungkapkan oleh para informan yang telah diwawancarai. Seperti kita ketahui, setiap individu membutuhkan pendidikan dan pembelajaran didalam hidupnya sepanjang hayat.

Dengan mendapatkan pendidikan di luar sekolah, setiap individu dapat memperoleh pengetahuan dan pengalaman baru yang bermanfaat bagi perkembangan dirinya. Jalur pendidikan di luar sekolah dapat dibagi menjadi beberapa kelompok, di antaranya; lembaga kursus dan pelatihan, kelompok belajar, pusat kegiatan belajar, majlis ta'lim dan satuan pendidikan sejenis lainnya. Pendidikan nonformal ialah setiap kegiatan terorganisas dan sistematis di luar sistem persekolahan yang mapan, dilakukan secara mandiri atau merupakan bagian penting dari kegiatan yang lebih luas, yang sengaja dilakukan untuk melayani peserta didik tertentu didalam mencapai tujuan belajaranya (Syamsi, 2010).

Tindakan sosial merupakan tindakan yang berhubungan dengan orang lain baik antar-individual atau antarkelompok. Max Weber memberikan batasan tindakan sosial sebagai tindakan seorang individu yang dapat memengaruhi individu-individu lainnya dalam masyarakat. Max Weber mengklasifikasikan ada empat jenis tindakan sosial yang memengaruhi sistem dan struktur sosial masyarakat. Keempat jenis tindakan sosial itu adalah tindakan rasional instrumental, tindakan rasional yang berorientasi nilai, tindakan tradisional, tindakan afektif (Syukur, 2018).

Tindakan sosial rasional instrumental. Tindakan yang memperhitungkan kesesuaian antara cara dan tujuan yang dengan mempertimbangkan efisiensi dan 
efektivitas (kemudahandan kehematan) dari sejumlah pilihan tindakan, maka tindakan tersebut dikategorikan sebagai tindakan sosial rasional instrumental. Dengan demikian, tindakan rasional instrumental lebih menekankan pada rasio (akal) sebagai alat yang digunakan untuk mendasari tindakan tersebut, yang selanjutnya diikuti oleh sejumlah tujuan-tujuan yang ingin dicapai, sehingga tindakan ini dalah tindakan yang masuk akal. Sedangkan tindakan sosial berorientasi nilai. Tindakan ini selalu didasarkan pada nilainilai dasar yang berlaku didalam masyarakat. Pelaku atau objek yang melakukan tindakan tidak mempermasalahkan tujuan dan tindakannya tetapi lebih mempermasalahkan caracara tindakan tersebut.

Dalam penelitian ini, masyarakat petani singkong dalam meningkatkan pendidikan yang ada di Keluarahan Sapaya dapat dilihat dengan tindakan yang dilakukan. Tindakan yang dilakukan petani singkong dapat dilihat dari empat tipe tindakan menurut Max Weber, dimana petani singkong dapat bertindak atas pertimbangan dan pilihan sadar yang berhubungan dengan tujuan tindakan yang dilakukan. Petani singkong dapat bertindak dengan memperhitungkan aspek rasional terutama pada upaya dalam memperbaiki tingkat pendidikan yang mulanya rendah, dalam meningkatkan pendidikannya masyarakat petani singkong memberikan dorongan dan dukungan kepada anak-anaknya untuk melanjutkan pendidikannya dengan memasukkan anak-anaknya kesekolah dan tempat belajar yang diinginkan, seperti menyekolahkannya di Sekolah Dasar (SD/MI), Sekolah Mnengah Pertama (SMP/MTs) dan Sekolah menengan Atas (SMA/MA), bahkan sampai ke perkulihan. Sedangkan untuk pendidikan nonformal, anak-anak atau masyarakat di tempatkan pada pembelajaran di luar sekolah seperti lembaga kursus dan pelatihan, kelompok belajar, pusat kegiatan belajar, majlis ta'lim dan satuan pendidikan sejenis lainnya.

Hasil penelitian ini relevan dengan penelitian (Ansar \& Syukur, 2018) dimana hasil dari penelitian ini menunjukkan bahwa relevan dengan hasil penelitian terdahulu yaitu hasil terdahulu adalah motivasi orang tua petani dalam mendorong anak-anaknya dalam melanjutkan pedidikan keperguruan tinggi, yaitu adanya dukungan dan menfasilitasi anak untuk berpendidikan. Dari hasil Dalam penelitian ini, masyarakat petani singkong dalam meningkatkan pendidikan yang ada di Kelurahan Sapaya dapat dilihat dengan tindakan yang dilakukan.

Tindakan yang dilakukan petani singkong dapat dilihat dari empat tipe tindakan menurut Max Weber, dimana petani singkong dapat bertindak atas pertimbangan dan pilihan sadar yang berhubungan dengan tujuan tindakan yang dilakukan. Petani singkong dapat bertindak dengan memperhitungkan aspek rasional terutama pada upaya dalam memperbaiki tingkat pendidikan yang mulanya rendah, dalam meningkatkan pendidikannya masyarakat petani singkong memberikan dorongan dan dukungan kepada anak-anaknya untuk melanjutkan pendidikannya dengan memasukkan anak-anaknya kesekolah dan tempat belajar yang diinginkan, seperti menyekolahkannya di Sekolah Dasar (SD/MI), Sekolah Mnengah Pertama (SMP/MTs) dan Sekolah menengan Atas (SMA/MA), bahkan sampai ke perkulihan. Sedangkan untuk pendidikan nonformal, anakanak atau masyarakat di tempatkan pada pembelajaran di luar sekolah seperti lembaga kursus dan pelatihan, kelompok belajar, pusat kegiatan belajar, majlis ta'lim dan satuan pendidikan sejenis lainnya.

Perbedaan yang kemudian muncul dalam penelitian ini jika dikaitkan dengan penelitian terdahulu, yaitu peneliti terdahulu lebih merujuk kepada latar belakang seseorang untuk melanjutkan pendidikan, faktor yang menjadi penyebab terjadinya putus sekolah dan tidak lanjutnya ke jenjang selanjutny dan bentuk-bentuk dorongan untuk 
melanjutkan pendidikan terhadap anak petani. Sedangkan penelitian ini merujuk kepada faktor penyebab terjadinya putus sekolah dan tidak lanjutnya ke jenjang selanjutnya serta upaya melanjutkan pendidikan pada masyarakat petani singkong kelurahan spata kecamatan bungaya kabupaten gowa. Faktor penyebab terjadinya putus ekolah dan tidak lanjutnya ke jenjang selanjutnya yaitu faktor kesadaran diri sendiri, faktor ekonomi, faktor pergaulan dan faktor kurangnya minat belajar. Keempat faktor tersebut yang menjadi pengaruh besar dam terjadinya putus sekolah dan tidak lanjutnya ke jenjang selanjutnya. Sedangkan upaya yang dilakukan yaitu mendukung anak-anak untuk berpendidikan dalam bentuk pendidikan formal dan pendidikan nonformal di masyarakat petani singkong di kelurahan sapaya kecamatan bungaya kabupaten gowa.

\section{PENUTUP}

Penelitian ini mengenai tentang faktor yang menyebabkan rendahnya minat pendidikan dan upaya yang bisa dilakukan untuk meningkatkan pendidikan masyarakat petani singkong merupakan faktor penyebab terjadinya perubahan minat pendidikan dan upaya pendidikan pada masyarakat petani singkong Kelurahan Sapaya, Kecamatan Bungaya Kabupaten Gowa. Diharapkan penelitian ini dapat memberikan sumbangan pemikiran ilmiah bagi pengembangan keilmuan dan berguna baik penulis karena mendapatkan informasi sekaligus aplikasi ilmu penulis di bangku kuliah dalam ranah sosial dan pendidikan khususnya ilmu sosiologi serta dapat dijadikan sebagai bahan informasi bagi masyarakat tentang perubahan minat pendidikan dan upaya pendidikan pada masyarakat petani singkong Kelurahan Sapaya, Kecamatan Bungaya Kabupaten Gowa.

\section{DAFTAR PUSTAKA}

Ansar, H., \& Syukur, M. (2018). Strategi Keluarga Petani dalam Melanjutkan Pendidikan Anak ke Perguruan Tinggi di Desa Pebaloran Kecamatan Curio Kabupaten Enrekang. Sosialisasi, 5(Nomor 1), 57-61. Retrieved from https://ojs.unm.ac.id/sosialisasi/article/view/12199/7207

DKB, D. K. B. (2007). Psikologi pendidikan.

Hidayat, M. A., Anwar, A., \& Hidayah, N. (2017). Pendidikan Non Formal Dalam Meningkatkan Keterampilan Anak Jalanan. EDUDEENA: Journal of Islamic Religious Education, 1(1).

Indonesia, P. R. (2005). Peraturan Pemerintah Nomor 19 tahun 2005 tentang Standar Nasional Pendidikan. Jakarta: DepartemenPendidikan Nasional.

Miles, M. B., \& Huberman, A. M. (1994). Qualitative data analysis: An expanded sourcebook. sage.

Seknun, M. Y. (2014). Telaah kritis terhadap perencanaan dalam proses pembelajaran. Lentera Pendidikan: Jurnal Ilmu Tarbiyah Dan Keguruan, 17(1), 80-91.

Syamsi, I. (2010). Pendidikan Luar Sekolah Sebagai Pemberdaya Dalam Masyarakat. Diklus, 14(1).

Syukur, M. (2018). Dasar-Dasar Teori Sosiologi. PT. Rajagrafindo Persada.

Tarpuhawa, P. (2018). Persepsi masyarakat petani bunga pada pendidikan formal anak di Desa Sidomulyo Kecamatan Batu kota Batu. Universitas Islam Negeri Maulana Malik Ibrahim.

Upe, A. (2016). Metode Penelitian Sosial: Filosofi dan Desain Praktis. Kendari: Literacy Institute. 